\title{
Representation of Dangerous Sexuality in Interwar Non-Fiction Sex Hygiene Films: A Franco-German Comparison*
}

Joël Danet

\section{Summary}

In the interwar period VD prevention films accompanied the introduction of new "permanent" treatments for syphilis. While they still warned the audience about the dangers of infection, these films were primarily designed to inform about these new methods for curing syphilis. These methods could only be effective if the infected patient immediately consulted a certified doctor (as opposed to a charlatan) upon experiencing the first symptoms.

The objectives of the commissioners of health education films tended to go beyond simply conveying a propaganda message. They adhere to and act on the educational potential that the film medium offers to an adult audience. In addressing subjects like sexual health, the films speak to the intimate lives of the audience members, faced with characters whose sexual behaviour is meant to echo their own or that of their friends and relatives. In order to properly raise awareness, the film must escort them, help them overcome their disarray, and persuade them that they are morally able to adopt the necessary measures to avoid contagion.

This paper consists in an in-depth comparative study of three anti-venereal films produced and shown between 1928 and 1931, a short but pivotal

* This article is the result of a collaboration with Vincent Lowy. It was presented at the Film \& Science: Fiction, Documentaries and Beyond conference held October 30 to November 2, 2008 in Chicago. The author wishes to thank Vincent for his considerable input.

This research received support from the Excellence Initiative of the University of Strasbourg funded by the French government's Future Investments program. It was conducted with the support of Interreg IV Upper Rhine OS A25 Rhinfilm project, cofinanced by the European Union - European Regional Development Fund (FEDER) "Transcending borders with every project" and the ANR project MEDFILM. We are grateful for copy-editing by Jean-Yves Bart.

Joël Danet, SAGE, UMR 7363, Sociétés, acteurs, gouvernements en Europe, Faculté de Médecine, Université de Strasbourg, 4 rue Kirschleger, 67085 Strasbourg Cedex, (danet@unistra.fr) 
period in the development of continental European syphilis prevention films. The three films illustrate two forms of screenplay action. In the French films, the patient is identified with a tragic hero and the medical institution embodied by a providential man. Contrary to these French films, the German film tends to display a more matter-of-fact-approach, which is not meant to downplay the risks but rather to clearly identify and address the community exposed to danger and to present how the infection is taken care of once it is diagnosed. Here I consider these films together to show how different ways of conveying the same medical discourse were adopted to adjust to national cinematographic environments.

Keywords: syphilis, drama, information, city, German(y), France

\section{Introduction}

In 1941, the well-known author Stefan Zweig reflected in his autobiography on how youth in early twentieth century Europe had been haunted by the peril of venereal disease:

$[\ldots]$ for it must not be forgotten that forty years ago sexual diseases were spread a hundred times more than they are today, and that they were a hundred times more dangerous and horrible in effect, because medicine did not yet know how to approach them clinically. Science could not yet cure them quickly and completely as it does today, so that now they are no more than episodes. Whereas today, thanks to Paul Ehrlich's therapy, in the clinics of the small and medium-sized universities weeks often pass by in which the professor is unable to show his students a freshly infected case of syphilis, the statistics of those days show that in the army and in the big cities at least one or two out of every ten young men had fallen victim to infection. ${ }^{1}$

In Europe and the US in the 1920s, the response to this threat included investment in massive communication campaigns against major scourges like tuberculosis, syphilis, alcoholism, cancer and VD, as traditional public hygiene was transformed into a twentieth century understanding of public health. This is true especially of venereal disease health education campaigns, for which private and public stakeholders used print media, conferences and theatrical and visual arts. As a "modern" communication technology, film played a significant part in this development. ${ }^{2}$

This paper consists in an in-depth comparative study of three anti-venereal films produced and shown between 1928 and 1931, a short but pivotal period in the development of continental European syphilis prevention films: Le baiser qui tue (A kiss that kills) is a 69-minute French black and white

1 Zweig 1943, 88.

2 See for example: Eberwein 1999; Pernick 1999; Parascandola 2007. 
picture directed by Jean Choux and released in 1928. It was written by Dr. Tartarin Malachowski with the support of the French ministry for labour and hygiene (Ministère du travail et de l'hygiène) and the Musée social. ${ }^{3}$ It was followed in 1929 by Il était une fois trois amis (Once upon a time three friends) a 54-minute black and white educational directed by the prolific French film director Jean Benoit-Lévy and his assistant Marie Epstein with financial support from the Commission générale de propagande de l'Office nationale d'hygiène sociale. ${ }^{4}$ Finally we will examine Walter Ruttmann's Feind im Blut, a 76-minute-long black and white picture produced in 1931 in Germany. ${ }^{5}$

In the interwar period, VD prevention film accompanied the introduction of new "permanent" treatments for syphilis. ${ }^{6}$ While they still warned the audience about the dangers of infection, these films were primarily designed to inform about these new methods for curing syphilis. These methods could only be effective if the infected patient immediately consulted a certified doctor (as opposed to a charlatan) upon experiencing the first symptoms. These films aimed to make knowledge more accessible to the public.

These 1920s anti-syphilis films sought to spread the "good news" about the cure for syphilis while cautioning to remain vigilant. Their common target is prostitution, which proliferated as cities developed, but also served as a convenient scapegoat to avoid discussing the domestic sphere, even though there were similarly numerous contagion cases among couples. The three films analysed in this paper have different ways of delivering a similar message. The differences in mise-en-scène stem as much from stylistic choices as from the broader approach that determined the content. The FrancoGerman comparison displays a contrast between a moralistic approach and one of informative pragmatism. This is observed at two key moments in the narrative aimed at prevention: the description of the infectious milieu to which the ordinary citizen is exposed and the circumstances in which the disease is identified and treated. These moments involved, on the one hand, the modern city as a place of nocturnal entertainment, and on the other, the medical institution as a place of education and intervention.

3 Lefebvre 2004.

4 For earlier accounts on films by Choux and Benoit-Lévy see: Gertiser 2008. Gertiser 2009 and Vignaux 2007.

5 For Ruttmann: Fulks 1982; Goergen 1989; Loiperdinger 1995, 43-56; Cowan 2013.

6 That is, with arsenic remedies, Salvarsan in 1910 and Stovarsol in 1921. See Huentelmann 2011. 
The objectives of the commissioners of health education films tended to go beyond simply conveying a propaganda message. They adhere to and act on the educational potential that the film medium offers to an adult audience. According to the psychologist Hugo Münsterberg in his 1916 study, The Photoplay: A Psychological Study, cinema invents an appropriate context for public education, and surpasses print with the impact of its images. As such, it is ideal to aid civic causes and to elevate the mind of the spectator:

The masses of today prefer to be taught by pictures rather than by words. The audiences are assembled anyhow. Instead of feeding them with mere entertainment, why not give them food for serious thought? [...] Political and economic, social and hygienic, technical and industrial, aesthetic and scientific questions can in no better way be brought nearer to the grasp of millions. ${ }^{7}$

This is effectively what the most successful VD prevention films achieve, particularly when addressing a subject like sexual health. They speak to the intimate lives of the viewers, faced with characters whose sexual behaviour is meant to echo their own or that of their friends and relatives. In order to properly raise awareness, the film must escort them, help them overcome their disarray, and persuade them that they are morally able to adopt the necessary measures to avoid contagion.

Fifteen years after Münsterberg's analysis, Lucien Viborel, a significant figure of hygiene propaganda in France revisited the educational value of the film media and argued that cinema should not lose its entertainment value and accessibility to as broad an audience as possible even when it intended to fulfill an educational mission:

In a conference words travel by air but they only touch a limited number of listeners. Film can run forever, in any country, on all latitudes; it can be seen by the most innocent eyes and through simple and amusing plots it can distract the young and the elderly, and along the way deconstruct many preconceived ideas. In this sense film is ideally suited to popular instruction. ${ }^{8}$

The three films under consideration here illustrate two forms of screenplay action. In the French films, the patient is identified with a tragic hero and the medical institution embodied by a providential man as shown in Le baiser qui tue by Jean Choux (1928, FR). The latter film exemplifies the impressionist trend led by Jean Epstein and Louis Delluc; conjuring a dreamlike, borderline fantasy atmosphere, this tormented work conveys the longing of a marine during a long crossing, away from his wife. A different approach is at work in one of several films by Jean Benoit-Lévy, Il était une fois trois amis (1929). Adopting the formula of contrasting right and wrong behaviour that he is so fond of, Benoit-Lévy proposes an edifying tale that narrates the

7 Münsterberg [1916] 2002, 57.

8 Viborel 1930. 
fallout of a night in a cabaret for three friends. Contrary to these French films, the German film tends to display a more matter-of-fact-approach, which is not meant to downplay the risks but rather to clearly identify and address the situations where the community is exposed to danger and to present how the infection is taken care of once it is diagnosed. Walter Ruttmann's 1931 film Feind im Blut displays the boldness of his earliest avant-garde work. Although the narration is structured around recurring characters, a student and a bourgeois man, the Ruttmann film is centred on the hectic scene of the modern metropolis where venereal disease propagates.

All three films were projected in several countries: Siegfried Kracauer reviewed Choux's film in the Frankfurter Zeitung ${ }^{9}$ and André Cavaillon wrote that Feind im Blut was projected in nearly every cinema in France. ${ }^{10}$ Here I consider these films together to show how different ways of conveying the same medical discourse were adopted to adjust to national cinematographic environments. I also show that the films alternatively reflect Münsterberg's preoccupations (elevating the mind by providing serious information) and Viborel's concerns (edifying the audience in an entertaining manner).

\section{The pathogenic milieu: The myth of the den of vice and the reality of public space}

In all three films, the milieu in question is clearly that of the city, and more specifically urban areas devoted to nightlife and prostitution. The city is where the main characters become infected with syphilis after having been lured by the promise of pleasure. The viewer is invited to be wary of the charms of the city, where social intermingling is promoted, temptation is rife and hygiene lacking - a recipe for contamination. Yet, the delivery of this message varies between the films, which reflect different conceptions of prevention, one that emphasizes moral aspects (in the French films) and another preferring to acknowledge changing lifestyles with lucidity (the German film). This opposition is both political and stylistic. In Le baiser qui tue, as in Il était une fois trois amis, the message of prevention carries clearly moralistic undertones. The character who visited the city's dark underbelly is haunted by guilt and in search of redemption and medical help. In the German film Feind im Blut, the reality of modern society is acknowledged:

9 Kracauer 1928.

10 Cavaillon 1931.

Gesnerus 72 (2015) 
new behaviours putting individuals at risk may have emerged, but it is also shown that there is more knowledge and equipment available to limit their negative impact. ${ }^{11}$

The nightlife scene is pivotal in this respect. In Ruttmann's Feind im Blut, it is particularly ambitious visually; the change in time and space apparent. Anonymous seductions, chance encounters, mingling crowds, flashing lights, dark shadows, bar hopping are all shown. We see the character standing motionless in amidst the constant activity surrounding him. The audience is led to understand that he is unaware of what is happening and has lost control of his actions. His vulnerability is worsened by the fact that there is no public supervision to protect him from the dangers of the night. The storefronts are lined with alluring women who arouse the desires of the passersby. As the main protagonist enters a dancehall, his gaze is drawn to two women playing footsies underneath a table; then, as the orchestra launches into a Viennese valse, they get up to dance lasciviously with strangers. The music changes, moving to gypsy rhythms, jazz, then flonflon, as we move from one nightlife spot to another, an outdoor café-chantant, a cabaret, a corner bar, the street. There is a quick succession of medium shots and closeups, showing faces, glasses on the counter, feet on the floor, halting on the cogwheels of a barrel organ that plays the same tune as the dancehall orchestra. The melody that lingered over the white-clothed tables, where patrons dressed in the latest fashion gather, becomes that of a mechanical saw accompanying the drowsiness of the last customers. The scenes are united not only by a musical leitmotiv but also by the presence of the same characters; the audience will have recognized the student and the fat bourgeois man that he was introduced to at the beginning of the film. They meet and stick together for the whole night, drinking into the wee hours of the morning to cap off a night of excess and debauchery. In a familiar move the night that began in a fancy dancehall ends in a dingy dive. A trajectory determined by the opening hours of the establishments and familiarity with the urban geography of entertainment. The bartender pulls the last beer - only foam while the student walks up the street alone in the pale light of dawn, a train whistle sounding in the background, probably carrying his friend home. The director uses daring avant-garde techniques to paint a dreary, soberingly realistic picture of a night of drunkenness and debauchery.

11 Dumont 1987. 
For Choux and Benoit-Lévy, the risk also comes from the city. Yet, where Ruttmann's depiction is almost kaleidoscopic, they use just one setting to represent the city. Instead of seeing the characters drifting in a crowd and exposed to multiple lures, we witness a single meeting with a female temptress who embodies danger. "What a noxious night!" ${ }^{2}$ cries one of the friends in Benoit-Lévy's Il était une fois trois amis, recalling a night out in a music hall when they were military conscripts. An iris shot closes around his anxious expression as, in a flashback, he remembers the night when, like one of his friends, he let himself be seduced. The scene focuses on the dance that paired the characters with their temptresses, the prelude to the infectious sexual act. When the film returns to the present, we see the wives of the three friends, dressed in flowing white, frolicking in the fields, surrendering to the innocent joy that comes with a visit to the country, in perfect opposition to the cabaret women, with their dark dresses, calculated gestures and artificial expressions of happiness in the sealed place where all willpower disappears.

In Choux's Le baiser qui tue, the hero, a marine named Yves Le Goff, frequents a cabaret during a stopover in a port. As in Ruttmann's film, the soliciting of prostitutes is suggested as the camera closes in on the legs of a man and a woman together on the edge of a sidewalk. But the following sequence is very different in tone, consisting of a succession of fantasy-like images: marines gather in front of an accordionist whose music inspires a fleeting yet insistent vision of cabaret dancers. The silhouette of their undulating bodies blends with a superimposition of the sea's tumultuous waves. An erotic intertitle follows: "the soft kisses of the wind move over their chest and desire bites them ..." ${ }^{13}$ Jean Choux, who had written poetry himself, borrowed this line from the poet Emile Verhaeren. ${ }^{14} \mathrm{He}$ also drew from Victor Hugo's Travailleurs de la mer. The cabaret, which he portrays as the scene of the infection, with its suggestive shadows and eerie characters, has the same fantastical allure as the harbours described by Hugo. As he described the cabaret as the crucible of destinies, Hugo wrote: "An angel may be discovered in the slums; a pearl in the dunghill. Such sad and bewildering discoveries are not altogether unknown." 15 Such exalted oxymorons inspired Choux's superpositions, lending a magic quality to the story's locations, portrayed as impenetrable enigmas.

12 Original intertitle: "Quelle soirée néfaste!"

13 Original intertitle: "Les baisers mous du vent sur leur torse circulent et le désir les mord..."

14 Verhaeren [1893] 1920, 169.

15 Hugo 1866, 160. 
A curse appears to draw the character to the place of infection. Le Goff, a hot-blooded soul driven by desire, allows himself to be seduced by a woman he meets in a bar, as he had feared would happen. The scene echoes another in La maternelle, a film directed by Benoit-Lévy in 1933. Like Choux's marine, one of the female figures struggles between the desire to be a good mother and her yearning for men, but she gives in to her impulse and goes out to a cabaret. Benoit-Lévy, like Choux, shows her emotional confusion resonating with the hazy atmosphere of the festive location, smothered in shadows, where temptation is simultaneously dreaded and coveted. In both of these clips, the festive and corruptive dimension of the city acts as a backdrop rather than a central element; they do not show several sites or social mixing. Choux's marine contracts the disease just as Benoit-Lévy's female character loses the custody of her child, because he has indulged in behaviour that does not meet the standards of public morals.

Ruttmann, in contrast, proposes a realistic vision of the modern city where all citizens mix. His visual approach recalls his 1927 urban symphony, Berlin: Die Sinfonie der Grosstadt, which showed places and human plight with clinical precision. By stringing the images together in a continuous montage that fuses them together, he aims to convey the idea of mobility between different strata.

Choux and Benoit-Lévy neglect to show the reality of the city, instead depicting it as a mental projection of the characters' conflicting impetuses. The temptation of lust that threatens their aspiration to decency, as a Hugolian "tempest in a skull" takes hold of them as they cross the threshold of the cabaret. For the audience, the characters' mental anguish, which deforms the appearance of the city as a common place, is not its own. The risk comes from the moral shift of the character; it is not a ubiquitous element of public space, as in Ruttmann's film. Unlike Choux or Benoit-Lévy, Ruttmann takes collective behaviour into account, showing it through the portrayal of two individuals, which helps the audience relate to the story and message. It is worth asking whether this difference in approach is rooted in the differences between the French and German contexts? Lionel Richard and Serge Dillaz showed how entertainment forms increasingly crossed borders starting at the turn of the century, with the music hall becoming popular all over Europe. ${ }^{16}$ In his description of French cabarets in France, Pierre Brochon emphasizes their contribution to social mixing, making urban boundaries more porous at night. ${ }^{17}$ Ruttmann observed similar trends in Germany; he was able to cap- 
ture the modernization of lifestyles on a continental scale. Likewise, in his urban symphony Berlin: Die Sinfonie der Grosstadt, he chose to film Berlin not for the city itself, but as a metropolis representative of European cities. This vibration of modernity driving an entire civilization is absent from the contemporary films by Choux and Benoit-Lévy, who draw on the eternal power of tragedy for the purposes of edifying the audience. The scene depicting medical care, which follows the scenes of the place of infection, follows the same logic: in Ruttmann, an anonymous medical profession dispenses knowledge and care, whereas in Choux and Benoit-Lévy, an individual doctor embodies a providential figure who gives the hero access to a redemptive cure.

\section{Medical information: drama or generic teaching}

In Le baiser qui tue, it is on his own initiative that Jean Choux's main character seeks advice on his ill-being. Upon returning to the ship after spending the night in the arms of a temptress, Le Goff believes himself infected. His distress leads him to consult the Larousse de la médecine, by Dr. Galtier Boissière, available on board. The medical dictionary reveals: "The disease enters like an insidious, devious, unspeakable guest, that spreads throughout our being, breaking it up and damaging it ..." ${ }^{18}$ This hazy, poetic explanation is then illustrated by a succession of clinical shots, excerpted from scientific films; first an animated sequence representing the contamination, then documentary clips of people suffering the ravages of the disease - one is crippled, shaken by convulsions, another is shown close up grinning idiotically. The next intertitle provides another citation from the dictionary, disclosing that the disease "is transmitted to up to four generations, producing monsters ..." ${ }^{19}$ It is followed by images of skeletal hydrocephalic children, front and profile shots on black backgrounds, then more children afflicted with the same deformity, limping down a path in a park. These images appear in seemingly random succession; no explanation is given as to their nature. Subsequently, the hero begins to imagine an octopus shaking its tentacles, and then the dishevelled ghost of his wife on a horse galloping through the night, an image reminiscent of John Haynes's preromantic etching Death on

18 Original intertitle: "La maladie entre en nous comme un hôte sournois, perfide, innommable, qu'elle se répand dans tout l'être, qu'elle se disloque et détraque..."

19 Original intertitle: "se transmet jusqu'à la quatrième génération, façonnant à plaisir des monstres..." 
a Pale Horse.$^{20}$ These delirious visions, symbolizing the fear of contamination, combine with the previous clinical shots to create a fanciful mental picture. In the first year within the release of Choux's film, this approach elicited a negative review in the Frankfurt Zeitung by German film theorist and critic Sigfried Kracauer, who was irritated by its heavy-handed and counterproductive romanticism. ${ }^{21}$

The revelation scene in Le baiser qui tue has its counter-model in Rudolf Biebrach's 1926 German film, Falsche Scham. In Choux's film, the hero's interest in informing himself about venereal disease is sparked by his isolation and solitude. In Biebrach, the educative elements precede the characters contamination, appearing in places where the hero is susceptible to be infected. Written by physicians Curt Thomalla and Nicolas Kaufmann, wellknown experts of health education film in Germany, the film tells of two young men going out to the fair. They are about to catch a cabaret number, when a stranger invites them to see the show on the other side of the alleyway: a preventive exhibition and lecture on syphilis. Inside, illustrated panels display anatomical wax casts of the ravages of the disease. In an adjacent room, a scientist presents the dangers of venereal diseases and the measures to take against them. The two young men are invited to peer through a microscope to glimpse the germs responsible for the disease. A micro-cinematographic image then shows the ring-shaped, quivering shapes, followed by waving black lines that begin to whiten: they see the disease as it progresses. The lecturer turns to the panel on the wall illustrating the male sexual organs, in the audience, viewed in reverse angle, a woman stifles a giggle as she looks at the person sitting next to her. But as the lecture progresses, the extent of the threat is revealed through the exhibition and the commentary explaining the scientific displays; the audience members no longer look for distraction. "Ladies and gentlemen! The best means of avoiding these dangers is to know them."22 The lecture ends and as the group disperses, the two young men look at one another in consternation. Their conscience has been enlightened; now it is up to them to act. Yet, it was through a somewhat clandestine path that the medical information reached them. This mise-en-scène is comparable to that in Das Cabinet des Dr. Caligari, also a story of two young men seeking amusement at a fair. However, here the turning point is not a

20 Dating back to 1784, this etching is mentioned by Charles Baudelaire in his 1857 poem Une gravure fantastique. John Haynes reproduced John Hamilton Mortimer's 1775 drawing of the same name.

21 Kracauer 1928.

22 Original intertitle: "Mesdames et messieurs! Le meilleur moyen pour éviter ces dangers est de les connaître." 
hypnosis session like in Robert Wiene's film, but a medical lecture that leads them to reason. This works as a metaphor of the health education film itself: you take the setting of an evening show and infiltrate the venue of entertainment (the fair, and the projection circuits) in order to raise awareness among citizens who are constantly stimulated by the industrial society and the entertainment available in urban settings.

In Ruttmann and Benoit-Lévy's films, medical information is slipped into the course of the film in much the same way. This apparent similarity ultimately contributes to highlighting the differences in their approaches. In Il était une fois trois amis medical information is given in a university lecture hall scene that is seamlessly tied into the plot. The main character, a doctor, attempts to explain the dangers of syphilis to his son. In his edifying story, the doctor effectively recounts the story to the viewer: the reverse angles multiplied by the camera suggesting the doctor's point of view bring the audience to understand that the story told to the doctor's son is equally about them. Exploiting the informative exposé to its fullest, the doctor repeats the same lesson he gives his students to his son, instructing by the same way the spectator. Through a complex mise-en-scène, Benoit-Lévy places the viewer amongst the students, alongside the son for whom the lesson is reproduced. At the beginning of the scene, a film projector fills the screen, followed by scientific images intercut with explanatory inserts. In the next scene, the projector is located in the back of an auditorium, behind the students sitting in the rows of seats. The viewer then understands that the scientific images shown on the screen were projected in that room to accompany the physician's lecture.

According to André Cavaillon, then head of the Ministère de l'Hygiène publique in France, this sequence from Il était une fois trois amis had a particularly strong impact on the public. In a 1931 article entitled "Cinema and the campaign against the danger of venereal diseases", depicting a screening of Benoit-Lévy's film he had attended himself, he recounts the effect of Albert Mourlan's animated sequence ${ }^{23}$ on the audience: "The music is stopped; in solemn silence the audience follows in an outline on the screen the contagion moving along the veins and arteries into the foetus, when the mother is diseased, by the work of treponemes." 24

23 Albert Mourlan (1887-1946) was a painter, cartoonist and filmmaker. He collaborated on several institutional films in the thirties.

24 Cavaillon 1931791. 
In Feind im Blut, Walter Ruttmann borrows the same principle as BenoitLévy. One of the heroes, a young student, attends a medical school lecture on syphilis after spending the night with a young temptress. In the auditorium where he takes a seat, the cast of a diseased face is passed around. ${ }^{25}$ When he takes it in his hand, he is troubled, as if he imagines that this could one day be his face. Like in Benoit-Lévy's film, a projector is used to complement the professor's lecture with scientific images, photographs and animations. Embedded in the lecture used as a narrative device, the threat of contamination is revealed to the student and thereby to the audience that had witnessed his night of debauchery earlier in the film. As in Benoit-Lévy's film, the disease's branding on the flesh is exhibited without moderation: the professor presents an infected young woman who undresses to display her torso covered with lesions.

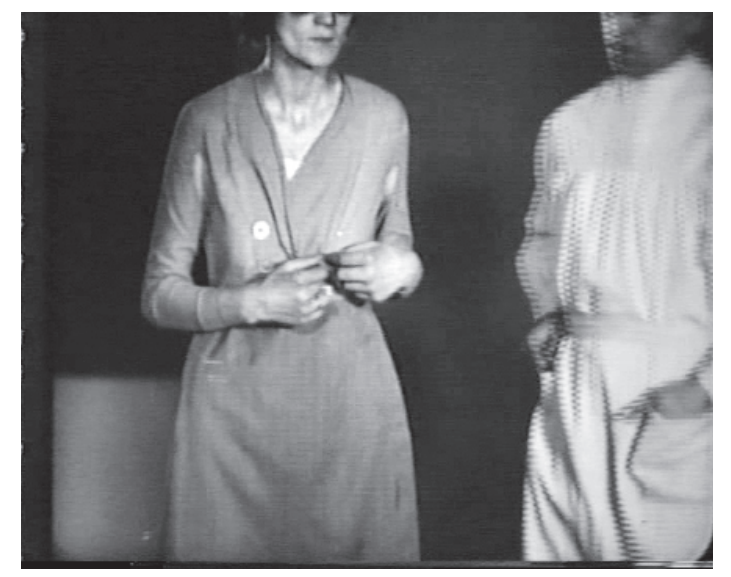

Illustration 1: Feind im Blut by Walther Ruttmann, 1931, 15'46"

Though Benoit-Lévy also shows a newborn baby to the students, in contrast to Ruttmann's film, his infected body is not visible to the film audience. Ruttmann exploits the context of the class as fully as possible to educate the audience, pushing the limits of public morality in order to exhibit the facts. According to Cavaillon's aforementioned article, Benoit-Lévy could not be as bold. His mise-en-scène is mindful of the moral code expected by French public opinion "speaking in the language that this public loves, that is to say, plainly and frankly but without vulgarity or brutality." ${ }^{26}$ Ruttmann was not hindered by similar concerns in the equivalent sequence in Feind im Blut.

In Ruttmann's film, it is worth noting that the physician is only present in this scene; otherwise absent from the rest of the story, he serves merely as an anonymous agent of medical scientific popularization. In Il était une fois trois

25 For that function of the casts in the film see: Laukötter 2011.

26 Cavaillon 1931, 792. 
amis, the doctor is a central character. Compellingly played by the charismatic actor Camille Bert, the doctor is filmed with particular care; the camera scrutinizes his facial expressions as he fights the disease. It is in his intense gaze and in his enigmatic yet benevolent smile as much as in his words that he conveys the wisdom he has gained through scholarship and experience. BenoitLévy has him speak as both a father and a medical doctor. In the same paternalistic manner, even if he is not addressing his son, the doctor featured in Choux's film reassures the marine that has come to consult him in desperation. The medical office is a place where one can clear his conscience between four walls before being treated. By depicting the doctor's office as a theatre, the medical consultation as a drama and the physician as a hero, Choux and Benoit-Lévy alike have recourse to the resources of fiction to address the venereal peril. For Cavaillon, this fictional packaging is inevitable to obtain the desired transformation in the audience's consciousness. He praised Il était une fois trois amis for addressing viewers using "the vivid form of living history instead of following the dry formula of a documentary film." ${ }^{27}$ Here fiction serves the purpose of sweetening the pill of the scientific information imparted in the film.

Both Choux and Benoit-Lévy accordingly present the concrete practice of treatment in elliptic forms. On the contrary, Ruttmann makes it the subject of a key sequence in Feind im Blut.

Illustration 2: Feind im Blut by Walther Ruttmann, 1931, 50'15"'

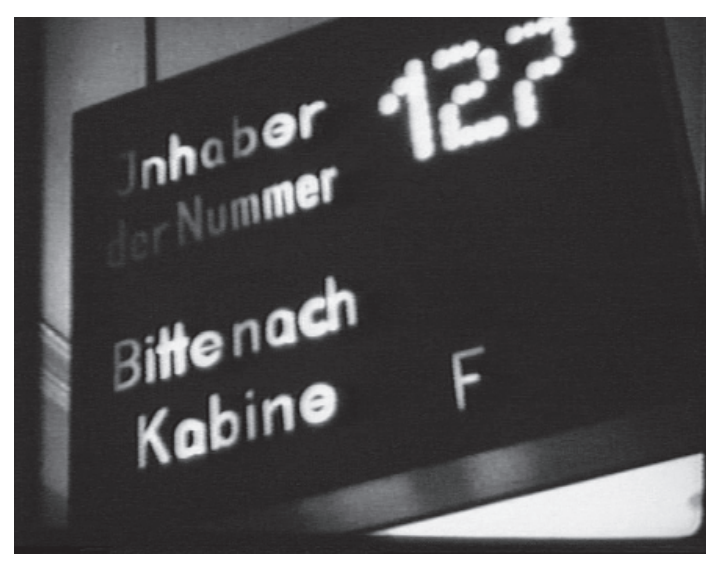

The student takes a seat in the office of a doctor specializing in venereal disease. On a switchboard, numbers and letters light up, a mechanical sorting system that sets the rhythm of the subsequent scenes, including a zoom in on a patient taking a blood test. No one stands out here: as a counterpoint to

27 Cavaillon 1931, 792. 


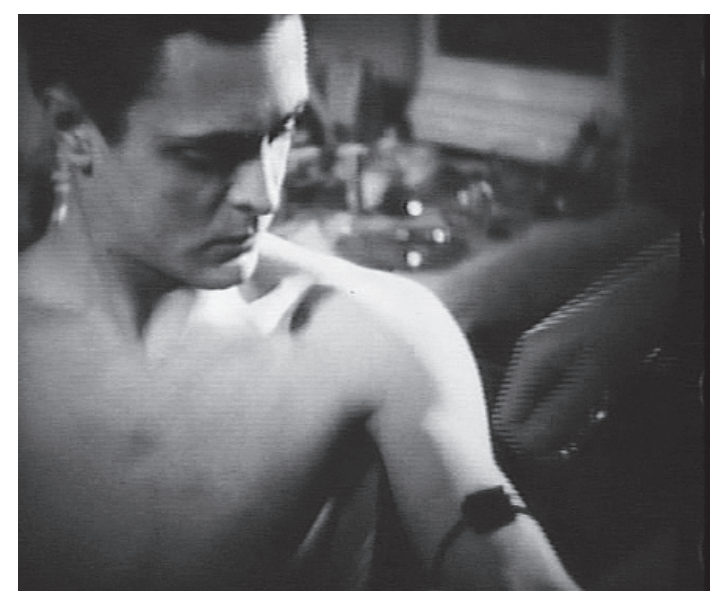

Illustration 3: Feind im Blut by Walther Ruttmann, 1931, 42'47'”

the nightlife sequence, the final sequence of medical treatment is filmed with the same painstaking care for documentary detail. In his study of medical cinema in the first half of the twentieth century, ${ }^{28}$ Adolf Nichtenhauser recalls a survey carried out in the early 1920s on the reception of anti-syphilis films commissioned in the United States. The investigators sought to establish whether fictional dramatization was more efficient than non-fiction or not. Based on their results they concluded that the audience responded to purely informative sequences just as well as those embedded within a narrative. For Adolf Nichtenhauser, whose writings date back to the 1950s, the data gathered in that survey remained relevant to educators and directors. Applying these results when viewing Ruttmann's film (produced ten years after the survey and twenty years before Nichtenhauser's judgment) it seems that Ruttmann was anticipating Nichtenhauser's advice. Fiction plays a minimal role in Feind im Blut: it mainly serves to provide a narrative framework for the immersive mise-en-scène. More important is the documentary restitution of the social reality to which the citizen is exposed. The film's approach to the danger about which it warned viewers consisted in a deliberate combination of boldly blunt, matter-of-fact documentary material on at-risk behaviour and of equally realistic yet reassuring scenes carefully depicting medical care.

\section{Conclusion}

In the three films under comparison it appears that the same preventive objective applied to moving images ultimately resulted in works that are comparable in terms of content: they show the city as a source of infection

28 Nichtenhauser c. 1950. 
for ordinary citizens and inform viewers about how the disease can be identified and treated. In contrast, the screenplays and directing styles of the two French films and the German film clearly showcase diverging concepts of hygienic film discourse: one conveying a pragmatic, evidence-based discourse, and the other promoting a normative discourse based on edification through storytelling. This reflects to some extent not only differences between the commissioners of the films but also diverging schools of film production in the two countries at the time.

Undoubtedly, as our comparative study concentrates on the late 1920s, it reflects a time when German cinema stood out through the consistency of its output, whose contents resonated closely with the collective expectations of German society. Although their interpretations diverged, two key studies on Weimar cinema emphasize this exceptional symbiosis. In his 1947 publication, De Caligari à Hitler, Kracauer seeks to demonstrate that the series of films produced in inter-war Germany reflect the stages of the ascent of Nazism as much as the psychological state of public opinion that allowed its triumph. ${ }^{29}$ Anton Kaes makes an opposite point in Shell Shock Cinema: Weimar Culture and the Wounds of War. ${ }^{30} \mathrm{He}$ argues that the trauma of the First World War is a key factor in the mise-en-scène of German film: people and places constitute the symbolic expressions of a backlash repressed on a national scale. Although at odds both of these interpretations consider cinema as the mirror of a nation: collective obsessions nourished the films and the films reinforced them in return. ${ }^{31}$ This relationship between the filmmakers and their audience benefited health education film, as in Feind im $B l u t$, in which the collective fear is embodied by the contaminating temptress. The documentary sequence of the film in particular adroitly conveys its preventive message, relying on suggestion and on the audience's interpretation skills, using sequences that replicate their urban experiences.

The two films by Benoit-Lévy and Choux are not similarly attuned to the social experience of the viewers, and pay little heed to the turpitudes of the era in which they were released. In her analysis of Il était une fois trois amis Valérie Vignaux points out that Benoit-Lévy's film juxtaposes two temporalities: an anachronistic and normative timeline intending to regulate social behavior imposing itself to a present-tense timeline receptive to the realities of a society in continuous transformation. One of the final intertitles

29 Kracauer 1947.

30 Kaes 2009.

31 It was likely not before the advent of the Front populaire that an equivalent dialogue between cinema and citizens emerged in France, as Geneviève Guillaume-Grimaud has sought to demonstrate. See Guillaume-Grimaud 1986. 
of Il était une fois trois amis encapsulates this paradox in one saying: "Happy individuals are like nations, those that have no history!" 32

Feind im Blut anticipates a filmic approach that would be pursued after World War II in documentary film production. Technically not yet accessible to interwar film production, it is direct cinema that favoured and fully played out presenting facts straighforwardly, rooting storytelling in the present and not in a "time of normativity" anymore thus inspiring serious thinking instead of merely serving up hygienic catechism.

\section{Bibliography}

Brochon, Pierre (ed.), La chanson française: Béranger et son temps (Paris 1956)

Cavaillon, André, "The Cinema and the Campaign against the Danger of Venereal Diseases", Review of Educational Cinema/Revue Internationale du Cinéma éducateur (1931) 789-795

Cowan, Michael, Walter Ruttmann and Multiplicity: Film - Advertising - Modernity (Amsterdam 2013)

Dillaz, Serge, La chanson sous la Troisième République, 1870-1940 (Paris 1991)

Dumont, Hervé, Histoire du cinéma suisse 1896-1965 (Lausanne 1987) 125-127

Eberwein, Robert, Sex ed. Film, Video, and the Framework of Desire (New Brunswick 1999)

Fulks, Barry, Film culture and Kulturfilm. Walter Ruttmann, the Avant-Garde Film and the Kulturfilm in Weimar Germany and the Third Reich, $\mathrm{PhD}$ University of Madison (Madison 1982)

Gertiser, Anita: Ekel. Beobachtungen zu einer Strategie im Aufklärungsfilm zur Bekämpfung der Geschlechtskrankheiten. In: Alain Boillat/Philipp Brunner/ Barbara Flückiger (Hg.): Kino CH/Cinéma CH. Rezeption, Ästhetik, Geschichte (Marburg 2008) 279-294

Gertiser, Anita: Falsche Scham. Strategien der Überzeugung in Aufklärungsfilmen zur Bekämpfung der Geschlechtskrankheiten 1915-1935 PhD Universität Zurich (Zürich 2009)

Goergen, Jeanpaul (ed.), Walter Ruttmann. Eine Dokumentation (Berlin 1989)

Guillaume-Grimaud, Geneviève, Le cinéma du Front populaire (Paris 1986)

Huentelmann, Axel, Paul Ehrlich, Leben, Forschung, Ökonomien, Netzwerke (Göttingen 2011)

Hugo, Victor, Toilers of the Sea (Paris 1866)

Kaes, Anton, Shell Shock Cinema: Weimar Culture and the Wounds of War (Princeton 2009)

Kracauer, Siegfried, "Ein französischer Aufkärungsfilm", Frankfurter Zeitung, 22/7/1928. Cited after: Kracauer, Siegfried, Werke. Band 6.2: Kleine Schriften zum Film 1928-1931(Frankfurt 2004) 102

Kracauer, Siegfried, De Caligari à Hitler: Une histoire psychologique du cinéma allemand (New York 1947)

32 Vignaux 2007. 
Laukötter, A., (Film-)Bilder und medizinische Aufklärung im beginnenden 20. Jahrhundert: Evidenz und Emotionen. In: Kathrin Friedrich(Sven Stollfuß (Hg.), Blickwechsel: Bildpraxen zwischen Wissenschafts- und Populärkultur (Augen-Blick: Marburger Hefte zur Medienwissenschaft No 50) (Marburg 2011) 24-38

Lefebvre, Thierry, "Le cinéma contre la syphilis - des débuts prometteurs", La revue du praticien 54 (2004) 2-5

Loiperdinger, Martin, "Neue Sachlichkeit und Nationalsozialismus. Zur Ambivalenz von Walter Ruttmanns Filmen für das 'Dritte Reich"', in: Manfred Hattendorf (Hg.), Perspektiven des Dokumentarfilms (Munich, 1995) 43-56

Münsterberg, Hugo, The Photoplay: A Psychological Study (New York [1916] 2002)

Nichtenhauser, Adolf, A History of Motion Pictures in Medicine (Unpublished manuscript, c. 1950)

Parascandola, John, "Syphilis at the Cinema: Medicine and Morals in VD Films of the U.S. Public Health Service in World War II". In: Leslie J. Reagan/Nancy Tomes/Paula A.Treichler (eds.), Medicine's Moving Pictures: Medicine, Health, and Bodies in American Film and Television (Rochester, N.Y., 2007) 71-92

Pernick, Martin, The black stork: eugenics and the death of "defective" babies in American medicine and motion pictures since 1915 (New York 1996)

Richard, Lionel, Cabaret cabarets (Paris 1992)

Verhaeren, Emile, Les villes tentaculaires (Paris [1893] 1920)

Viborel, Lucien, La technique de la propagande d'hygiène sociale (Paris 1930)

Vignaux, Valérie, Jean-Benoît Lévy ou le corps comme utopie (Paris 2007)

Zweig, Stefan, The World of Yesterday. An Autobiography (London 1943) 